\section{Assessing the Synergistic Effects of Co-digestion of Maize Silage and Red Chicory Waste}

\author{
A. Cortesi, V. Gallo, D. Solinas, and R. Vitanza* \\ University of Trieste, Department of Engineering \\ and Architecture via Alfonso Valerio, 6/1, \\ 34127 Trieste, Italy
}

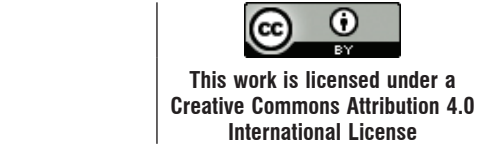

doi: 10.15255/CABEQ.2018.1300

Original scientific paper

Received: February 14, 2018

Accepted: September 15, 2018

\begin{abstract}
Nowadays, the anaerobic digestion of organic wastes to produce renewable energy is a reality in many countries. Many feedstocks can be processed by anaerobic digestion to produce biogas, however, anaerobic digestion of single substrates can have drawbacks that could be eliminated by the anaerobic co-digestion of their mixtures (two or more). In this paper, the anaerobic co-digestion of maize silage and red chicory (radicchio) waste is presented. Several batch anaerobic biodegradability tests were performed in order to compare the methane production of the blend with those of the two substrates digested separately. The methane production was modelled by a first order kinetic model, focusing on the initial substrate solubilization. The specific methane productions of maize silage and red chicory as single substrates were $0.346 \mathrm{~L} \mathrm{CH}_{4} \mathrm{~g}^{-1} \mathrm{ODM}$ and 0.326 $\mathrm{L} \mathrm{CH}_{4} \mathrm{~g}^{-1} \mathrm{ODM}$. The first solubilization rate constants $\left(k_{\text {sol }}\right)$ were $0.231 \mathrm{~d}^{-1}$ for the digestion of maize silage, and $0.389 \mathrm{~d}^{-1}$ for the radicchio waste. Two parameters representing the relative changes in specific methane production and solubilization rate were calculated in order to evaluate the synergistic effects due to co-digestion of studied substrates. Results showed that blending the two substrates enhanced the performances of the AD process, mainly with respect to biogas production kinetics with low increments in the ultimate methane potential.
\end{abstract}

Key words:

anaerobic co-digestion, anaerobic biodegradability, disintegration, specific methane production, theoretical methane potential

\section{Introduction}

The anaerobic digestion (AD) of organic waste is an attractive and sustainable technology for energy recovery and pollution prevention. The main product of $\mathrm{AD}$ is biogas (a mixture of $\mathrm{CH}_{4}$ and $\mathrm{CO}_{2}$ ) that may be used for heating and electricity production, and, if upgraded, may be used as vehicle fuel or injected in a natural gas network ${ }^{1}$. A secondary product of the process is a sludge residue, called digestate, which can be directly used as soil amendment or as starting material for high-quality compost preparation ${ }^{2}$.

Many feedstocks can be processed by $\mathrm{AD}$ to produce biogas, including the organic fraction of municipal solid waste (OFMSW), agro-industrial waste, agricultural residuals, energy crops, and sewage sludge. In recent years, Italy is witnessing a proliferation of biogas plants purpose-designed for energy recovery. The Italian biogas production is the second largest in the European Union after Germany $^{3}$. According to the EBA Statistics ${ }^{4}$, at the end of 2015 there were more than 1500 biogas plants

"Corresponding author: Rosa Vitanza, rosa.vitanza@dia.units.it, (0039) 0405583254 operating in Italy. Most of these operate in co-digestion and, consequently, are fed with energy crops (mainly cereal silage), agricultural by-products (animal sewage), and agro-industrial residues ${ }^{5}$. It is recognized that the simultaneous digestion of two or more organic substrates offers several advantages, such as the improvement of the balance of nutrients and the $\mathrm{C}: \mathrm{N}$ ratio, the alleviation of inhibitory effects due to toxic substances, and the enhancement of methane production kinetics ${ }^{6-11}$. However, selecting the blend of substrates leading to a stable anaerobic co-digestion (AcoD) operation is not trivial, as it requires knowledge and expertise on the process ${ }^{12}$. Co-substrate selection through optimization methods seems to be the way to facilitate synergistic effects during $\mathrm{AcoD}^{12,13}$. As reported in literature $^{14,15}$, the best co-substrate blend should assure: (i) a balanced carbon-to-nitrogen $(\mathrm{C}: \mathrm{N})$ ratio; (ii) a micronutrients equilibrium; (iii) a dilution of inhibitory and toxic compounds; (iv) a higher readily biodegradable organic fraction; (v) an optimized methane production, and (vi) enhanced digestate stability. Usually, the main criterion adopted, among all, to decide the best ratio between waste for AcoD process, is the optimization of the $\mathrm{C}: \mathrm{N}$ ratio ${ }^{15}$. 
In this paper, the effects of co-digestion of maize silage (MS), with waste coming from the harvesting of red radicchio (Cichorium intybus) (RR), were evaluated. The aim was to investigate the biovalorization via AcoD of RR waste by adding them to an ideal $\mathrm{AD}$ substrate, such as maize silage. Three scenarios were evaluated by means of anaerobic biodegradability tests: mono-digestion of maize silage and red radicchio separately, and co-digestion of mixed substrates. The methane production was modelled by a first order kinetic model, focusing on the initial substrate solubilization (disintegration plus hydrolysis). With a pragmatic approach, the synergistic effects due to substrate blending were assessed by calculating the relative change in the ultimate methane production and in the solubilization rate as a result of co-digestion in comparison with mono-digestion.

\section{Materials and methods}

\section{Inoculum}

Anaerobic sludge was collected from a biogas plant operating at a fruit and vegetable processing factory. Sludge was analyzed in order to determine dry matter (DM) and organic dry matter (ODM) according to Standard Methods ${ }^{16}$, while the total COD was measured according to the method developed by Raposo et et al. ${ }^{17}$ Soluble COD was measured by Hach-Lange test cuvettes. Before performing the anaerobic biodegradability tests, the sludge was pre-incubated for 15 days in order to deplete any residual biodegradable materials. The endogenous (i.e. with no external feed) specific methanogenic activity $\left(\mathrm{SMA}_{\mathrm{end}}\right.$ ) recorded during the incubation was $0.047 \mathrm{~g} \mathrm{COD}^{-\mathrm{CH}_{4} \mathrm{~g}^{-1} \mathrm{ODM} \mathrm{d}}{ }^{-1}$. After this degassing period, the sludge sample was diluted (almost 1.5 times) and fed into the reactor. The characteristics of the anaerobic sludge at the beginning of biodegradability tests were: $13.65 \mathrm{~g} \mathrm{~L}^{-1}$ of DM with a volatile content of $66.3 \% ; 12.48 \mathrm{~g} \mathrm{~L}^{-1}$ of total $\mathrm{COD}$, and $1.56 \mathrm{~g} \mathrm{~L}^{-1}$ of soluble COD.

\section{Substrates characteristics and calculation of the theoretical methane potential}

The characterization of the organic substrates addressed to anaerobic digestion is the first step in order to provide an estimation of their biomethane potential, and, therefore, to evaluate the economics of the system. When dealing with lignocellulosic materials (as the substrates treated here), one must pay attention to the content of lignin that is not degradable in anaerobic conditions, and that creates barriers for microbial degradation of cellulose ${ }^{18}$.

In the present paper, the chemical compositions of maize silage and red radicchio were adopted from literature.

The use of maize silage in biomethanation processes is well known ${ }^{19-22}$ and it is possible to state that, currently, biogas production is mainly based on the AD of this substrate 5 . Significant differences among the data can be noticed when comparing maize characterization from literature due to many factors, such as the plant variety, weather during cultivation, harvesting technology, and analytical methods $^{23}$. As an example, a maize characterization comparison is reported in Table 1.

In the present work, the characterization of Herrmann et al. ${ }^{22}$ was adopted, since their MS components values fall in an average range of Table 1.

Red radicchio of Treviso, named after the Italian region where it originated, belongs to an ancient crop cultivated in northern Italy (Veneto region) ${ }^{24}$. The agronomic, economic, and social importance, and overall typicality of RR have been recognized by the European Union, which awarded it, at the end of the 1990s, with the PGI (Protected Geographical Indication) label ${ }^{25}$. According to recent statistics $^{26}$, the Italian red radicchio production for the year 2016 exceeds 120,000 tons with an occupied area of approximately 7700 ha. Outside Italy, radicchio is now commonly being grown throughout Europe, Japan, the United States, Guatemala, Mexico and South America ${ }^{27}$. The onerous manufacturing process, required by this chicory to achieve its high qualitative and aesthetic level, results in a great amount of waste, around $30 \%$ of rejected radicchio heads ${ }^{28}$, that can be subjected to anaerobic digestion. As regards the composition of radicchio waste, the initial fractionation of organic matter between carbohydrates, proteins, and lipids was obtained from the CREA (Consiglio per la Ricerca in agricoltura e l'analisi dell' Economia Agraria) tables ${ }^{29}$ and, at a later stage, the total carbohydrates sharing was assumed from Wahid et al. ${ }^{30}$

Several methods exist in literature to estimate the theoretical methane potential of the organic substrates starting from the content of carbohydrates, proteins and lipids, with particular attention to lignocellulosic components ${ }^{21,31,32}$. In the present work, according to Angelidaki and Sanders ${ }^{33}$, the theoretical methane potential of the substrates components was calculated by Buswell's formula ${ }^{34}$ :

$$
\mathrm{C}_{\mathrm{a}} \mathrm{H}_{\mathrm{b}} \mathrm{O}_{\mathrm{c}}+\left(\mathrm{a}-\frac{\mathrm{b}}{4}-\frac{\mathrm{c}}{2}\right) \mathrm{H}_{2} \mathrm{O} \rightarrow\left(\frac{\mathrm{a}}{2}+\frac{\mathrm{b}}{8}-\frac{\mathrm{c}}{4}\right) \mathrm{CH}_{4}+\left(\frac{\mathrm{a}}{2}-\frac{\mathrm{b}}{8}+\frac{\mathrm{c}}{4}\right) \mathrm{CO}_{2}
$$


which provides the specific theoretical methane potential, $B_{0, \text { th ODM, }}$ related to volatile solids:

$$
B_{0, \text { th ODM }}=\frac{\left(\frac{\mathrm{a}}{2}+\frac{\mathrm{b}}{8}-\frac{\mathrm{c}}{4}\right) 22.4}{12 \mathrm{a}+\mathrm{b}+16 \mathrm{c}}\left[\mathrm{STP} \frac{\mathrm{LCH}_{4}}{\mathrm{gODM}}\right]
$$

Neglecting the contribution of lignin (not anaerobically biodegradable), the $B_{0, \text { th ODM }}$ of the complex substrates was then obtained as:

$$
B_{0, \text { th ODM }}=\frac{0.415 \mathrm{~L} \cdot x_{\mathrm{CH}}+0.496 \mathrm{~L} \cdot x_{\mathrm{P}}+1.014 \mathrm{~L} \cdot x_{\mathrm{L}}}{\mathrm{ODM}}\left[\mathrm{STP} \frac{\mathrm{LCH}_{4}}{\mathrm{~g} \mathrm{ODM}}\right]
$$

where $x_{\mathrm{CH}}, x_{\mathrm{P}}$ and $x_{\mathrm{L}}$ represent the fraction of carbohydrates without lignin $\left(\mathrm{C}_{6} \mathrm{H}_{10} \mathrm{O}_{5}\right)$, proteins $\left(\mathrm{C}_{5} \mathrm{H}_{7} \mathrm{O}_{2} \mathrm{~N}\right)$, and lipids $\left(\mathrm{C}_{57} \mathrm{H}_{104} \mathrm{O}_{6}\right)$ of the complex substrates, respectively.

The characteristics of tested substrates with the calculated methane potential are reported in Table 2 .

\section{Experimental set-up}

The anaerobic biodegradability tests were carried out in home-made equipment presented in Fig. 1. The anaerobic reactor consisted of a 5-L glass bottle placed in a controlled temperature environment (water bath with a Julabo MB heating immersion circulator) of $35^{\circ} \mathrm{C}\left( \pm 0.1^{\circ} \mathrm{C}\right)$, and mixed continuously with magnetic stirrers (ARE, Velp Scientific). A pressure transducer (RS Instrument) was connected to the bioreactor to outline the pressure changes during the test. A volumetric method with water displacement was used to measure the biogas produced ${ }^{35}$, with composition achieved by a gas analyzer (GA 2000 plus, Geotechnical Instruments). All the data were finally recorded by PC. The assembled pipelines were made of stainless steel and PTFE.

Three scenarios were considered: mono-digestion of MS, mono-digestion of RR, and co-digestion of MS-RR. The methane potential of each typology of feed (MS, RR, and blend) was evaluated by means of consecutive batch tests with an applied substrate to inoculum (S/I) ratio variable from $5 \%$ to $9 \%$ in ODM basis. For a given feed, the production of biogas was monitored and recorded for a variable time interval (from one to three weeks)

\begin{tabular}{|c|c|c|c|c|}
\hline Parameter & Units & 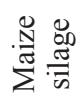 & 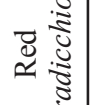 & $\begin{array}{l}0 \\
0 \\
0 \\
z\end{array}$ \\
\hline $\mathrm{DM}$ & {$[\%]$} & 33.3 & 5.3 & (a) \\
\hline ODM & {$\left[\begin{array}{ll}\% & \mathrm{DM}\end{array}\right]$} & 95.8 & 88.2 & (a) \\
\hline Carbohydrates $(*)$ & {$\left[\begin{array}{ll}\% & \mathrm{DM}\end{array}\right]$} & 82.5 & 60.2 & (b) \\
\hline Lignin & {$\left[\begin{array}{ll}\% & \mathrm{DM}\end{array}\right]$} & 2.9 & 5.9 & (b) \\
\hline Proteins & {$\left[\begin{array}{ll}\% & \mathrm{DM}\end{array}\right]$} & 7.8 & 20.5 & (b) \\
\hline Lipids & {$[\% \mathrm{DM}]$} & 2.6 & 1.5 & (b) \\
\hline Calculated COD & {$\left[\mathrm{gCOD} \mathrm{g}^{-1} \mathrm{DM}\right]$} & 1.21 & 1.14 & (c) \\
\hline $\mathrm{C} / \mathrm{N}$ & - & 35 & 13 & $(b-c)$ \\
\hline $\mathrm{COD} / \mathrm{N}$ & - & 97 & 35 & $(b-c)$ \\
\hline$B_{0 \text { th }}$ & [STP $\left.\mathrm{LCH}_{4} \mathrm{~g}^{-1} \mathrm{ODM}\right]$ & 0.425 & 0.416 & (c) \\
\hline
\end{tabular}

Table 2 - Characteristics of tested substrates

(*) without lignin

(a) from analysis, (b) from literature, (c) calculated

\begin{tabular}{|c|c|c|c|c|c|c|c|c|c|c|c|}
\hline $\begin{array}{l}\mathrm{DM} \\
(\%)\end{array}$ & $\begin{array}{c}\text { ODM } \\
(\% \text { DM })\end{array}$ & $\begin{array}{c}\text { Ash } \\
(\% \mathrm{DM})\end{array}$ & $\begin{array}{c}\mathrm{CP} \\
(\% \mathrm{DM})\end{array}$ & $\begin{array}{c}\text { CL } \\
(\% \mathrm{DM})\end{array}$ & $\begin{array}{c}\mathrm{CF} \\
(\% \mathrm{DM})\end{array}$ & $\begin{array}{c}\text { NDF } \\
(\% \text { DM })\end{array}$ & $\begin{array}{c}\mathrm{ADF} \\
(\% \mathrm{DM})\end{array}$ & $\begin{array}{c}\mathrm{ADL} \\
(\% \mathrm{DM})\end{array}$ & $\begin{array}{c}\text { NFE } \\
(\% \text { DM })\end{array}$ & $\begin{array}{l}\text { Starch } \\
(\% \text { DM })\end{array}$ & Ref. \\
\hline 31.0 & 95.5 & - & 6.7 & 2.9 & - & 34.6 & 21.6 & 2.0 & - & - & $19 *$ \\
\hline 30.2 & 95.8 & - & 7.8 & 2.6 & - & 41.2 & 24 & 2.9 & 64.7 & - & 22 \\
\hline 29.5 & 81.4 & 5.5 & 8.9 & 3.1 & 19.2 & 43.9 & 23.9 & 2.3 & - & 22.1 & 47 \\
\hline 31.1 & 93.2 & 6.8 & 10.3 & 5.1 & 15.5 & 71 & 33.4 & 11.6 & 62.4 & - & 36 \\
\hline
\end{tabular}

Table 1 - Literature data on characterization of maize silage

DM: dry matter; ODM: organic dry matter; CP: crude protein; CL: crude lipids; CF: crude fibers; NDF: neutral detergent fibre; ADF: acid detergent fibre; ADL: acid detergent lignin; NFE: nitrogen free extract.

* data relative to maize after 180 days of ensiling 


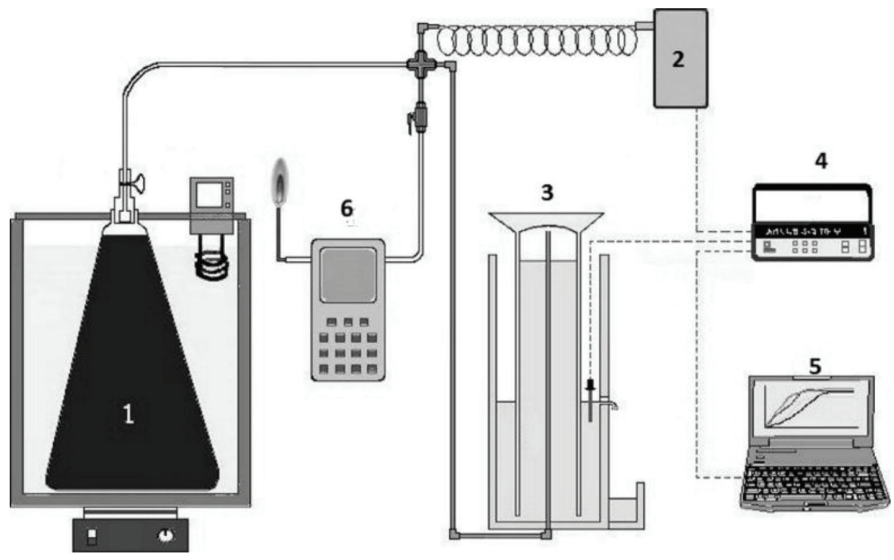

Fig. 1 - Experimental set-up: 1) anaerobic reactor; 2) pressure transducer; 3) gasometer; 4) data-logger; 5) personal computer; 6) gas analyzer

up to reaching the minimum biogas flow of $0.15 \mathrm{~mL} \mathrm{~min}^{-1}$ (value set as the proper limit for the production recording of the equipment).

The low $\mathrm{S} / \mathrm{I}$ ratio values were selected in order to reduce the reaction times allowing to maintain a biomass with a good activity and to focus the initial solubilization of particulate organic matter ${ }^{36,37}$. The strategy of operating consecutive batch tests was adopted to facilitate the biomass acclimatization to the substrate under investigation ${ }^{37}$.

\section{Results and discussion}

\section{Mono substrate digestion}

\section{Biodegradability tests}

The average values of specific methane production (SMP) obtained from the mono-substrate digestion were $0.346 \mathrm{~L} \mathrm{CH}_{4} \mathrm{~g}^{-1} \mathrm{ODM}$ for maize silage, and $0.326 \mathrm{~L} \mathrm{CH}_{4} \mathrm{~g}^{-1} \mathrm{ODM}$ for red radicchio waste, both resulting in agreement with literature data ${ }^{19,21,30}$.

The conversion efficiency was evaluated by dividing the average actual SMP of each substrate for its theoretical methane potential $B_{0 \text {,th ODM }}$, obtaining good performances for both feeds: $81.4 \%$ for maize silage, and $78.4 \%$ for red radicchio waste. It has to be pointed out that the practical methane yield is always lower than the theoretical one, due to several factors, such as: the utilization of a substrate fraction to synthesize new bacterial mass, the finite retention time, the limitation of nutrient factors, and the usual inaccessibility of a part of particulate organic substrates ${ }^{33}$. Undoubtedly, lignin plays a role in hampering the degradation of cell wall constituents. Herrmann et al. ${ }^{22}$ found a negative correlation between the specific methane production of crop silage and the parameters that describe the fiber fraction (namely, NDF and ADL). In order to enhance the anaerobic digestion of lignocellulosic matrices, Planinic et al. ${ }^{23}$ developed a pretreatment system of the corn forage by the white-rot fungus $T$. versicolor, obtaining a lignin degradation of $71 \%$. Applying the aforementioned pretreatment to corn silage before the co-digestion with cow manure, Tisma et al..$^{38}$ noticed an increase in methane generation rate.

The lower conversion efficiency of red chicory could also be due to its low value of C:N ratio. Astals et al. ${ }^{15}$ pointed out that values of $\mathrm{C}: \mathrm{N}$ from 20 to 60 are reported in literature as optimum for anaerobic digestion. Nevertheless, other authors observed long-term stable operation in a two-stage process (solid-state anaerobic digestion + granular biomass reactor) treating brewery spent grain at a very low $\mathrm{C}: \mathrm{N}$ ratio ranging from 0.16 to $4.69^{39}$.

\section{Solubilization rate}

Several authors agree that, for highly particulate organic matter, the initial hydrolysis is the rate-limiting step of the entire anaerobic digestion process $^{33,37,40}$. In ADM1, the breakdown of complex organic substrates to soluble monomers is modeled through the disintegration and hydrolysis stages ${ }^{41}$ : during disintegration, the composite substrate is divided into particulate carbohydrates, proteins and lipids that are further degraded, by the hydrolysis stage, into monosaccharides, amino acids and longchain fatty acids. The disintegration step and the three hydrolysis processes (for carbohydrates, proteins, and lipids, respectively) are assumed to follow first-order kinetics ${ }^{41}$.

The disintegration rate value $\left(k_{d i}\right)$ suggested by ADM1 for mesophilic digestion is $0.5 \mathrm{~d}^{-1}$, whereas the recommended hydrolysis constants for the carbohydrates, proteins, and lipids $\left(k_{\text {hyd_ch }}, k_{\text {hyd_pr }}, k_{\text {hyd_li }}\right)$ are set at the same value of $10 \mathrm{~d}^{-1}$.

In the present study, the first-order rate $k_{\text {sol }}\left(\mathrm{d}^{-1}\right)$ was evaluated to describe the initial solubilization (disintegration + hydrolysis) of the complex organic substrates. As reported by Astals et al. ${ }^{42}$, the solubilization rate has been typically estimated from the cumulative methane production curve of the anaerobic biodegradability test, and then implemented as disintegration rate in ADM1, while a default non-limiting value is given to the carbohydrates, protein, and lipids hydrolysis rate. This is in agreement with Feng et al. ${ }^{43}$, suggesting that the high values for $k_{h y d ~ c h}, k_{h y d ~ p r}$ and $k_{h y d ~ l i}$ are proposed in order to completely exclude the influence of hydrolysis step in the model.

Assuming that methane production was mainly limited by the solubilization rate with no accumulation of intermediate products, the cumulative meth- 
Table 3 -Evaluation of solubilization parameters

\begin{tabular}{c|c|c|c}
\hline Parameter & Units & MS & RR \\
\hline$S M P u_{l t}$ & {$\left[\mathrm{STP} \mathrm{LCH}_{4} \mathrm{~g}^{-1} \mathrm{ODM}\right]$} & 0.356 & 0.331 \\
$k_{\text {sol }}$ & {$\left[\mathrm{d}^{-1}\right]$} & 0.231 & 0.389 \\
\hline
\end{tabular}

Table 4 -Blend characteristics

\begin{tabular}{cccc}
\hline Parameter & Unit & Average value \\
\hline TS & {$[\%]$} & 21.6 \\
VS & {$[\% \mathrm{DM}]$} & 91.1 \\
Carbohydrates $\left(^{*}\right)$ & {$[\% \mathrm{DM}]$} & 73.3 \\
Lignin & {$[\% \mathrm{DM}]$} & 4.1 \\
Proteins & {$[\% \mathrm{DM}]$} & 13.0 \\
Lipids & {$[\% \mathrm{DM}]$} & 2.1 \\
C:N & - & 26 \\
$B_{\text {0th }}$ & {$\left[\right.$ STP L CH $\left.\mathrm{g}^{-1} \mathrm{ODM}\right]$} & 0.421 \\
\hline
\end{tabular}

ane production was represented by a first-order kinetic for the solubilization of particulate organic matter ${ }^{40}$ :

$$
S M P_{(t)}=S M P_{u l t} \cdot\left(1-e^{\left(-k_{s o l} \cdot t\right)}\right)
$$

where $S M P_{(t)}$ is the specific methane production ( $\left.\mathrm{L} \mathrm{CH}_{4} \mathrm{~g}^{-1} \mathrm{O} \mathrm{DM}\right)$ at time $t$ at standard conditions (STP), SMP ult is the ultimate methane potential (i.e., the production achievable at infinite residence time), and $k_{\text {sol }}$ is the total disintegration/hydrolysis constant.

The values of $S M P_{u l t}$ and $k_{\text {sol }}$ (reported in Table 3) were evaluated using non-linear least squares curve fitting on the net cumulative specific methane production (Fig. 2).

\section{Co-digestion tests}

The co-digestion tests were carried out by mixing maize silage and red chicory waste with a
MS:RR (in ODM basis) ratio ranging from 1.3 to 1.5 and a substrate to inoculum ODM ratio of $8 \%$ - $9 \%$. The blend composition (reported in Table 4) assured the optimal value of 26 for the $\mathrm{C}: \mathrm{N}$ ratio.

The theoretical methane potential of the co-substrates (also reported in Table 4) was predicted assuming the additivity of methane production obtaining a value of $B_{0 \text {,th ODM }}$ of $0.421 \mathrm{~L} \mathrm{CH}_{4} \mathrm{~g}^{-1} \mathrm{ODM}$ (in STP conditions).

The measured value of SMP was 0.371 (STP) $\mathrm{L} \mathrm{CH}_{4} \mathrm{~g}^{-1} \mathrm{ODM}$ with a conversion efficiency of $88.1 \%$.

To investigate the effects of co-digestion, an initial hypothesis of no-synergism was done so the blend methane production was simulated according to equation (4), modified to take into account the mixing ratio:

$$
\begin{aligned}
S M P_{\text {blend }(t)}= & x_{M S} \cdot S M P_{\text {ult MS }} \cdot\left(1-e^{\left(-k_{\text {sol MS }} \cdot t\right)}\right)+ \\
& +x_{R R} \cdot S M P_{\text {ult RR }} \cdot\left(1-e^{\left(-k_{\text {sol } R R} \cdot t\right)}\right)
\end{aligned}
$$

where $x_{M S}$ and $x_{R R}$ represent the ODM fraction of single substrate with respect to the blend feed.

In Fig. 3, the comparison between the measured SMP (scattered curve) and the predicted one (continuous line) calculated with equation (5) is shown. As it is evident, the measured production curves are always above the calculated ones, in agreement with Mata-Alvarez et al. ${ }^{44}$ and Aichinger et $a l .{ }^{45}$ stating that, under favorable conditions, $1+1>2$ may be achieved, i.e., the co-digestion of two substrates can produce more methane than the addition of the methane produced in both single-substrate digestions. The synergism between the two substrates had a clear beneficial effect on the solubilization rate: as shown in Fig. 3, the actual disintegration/hydrolysis step was faster than the predicted one.

In order to measure the observed synergistic effects, two parameters were considered: $\triangle S M P_{\text {blend }}$ and $\Delta k_{\text {blend }}$.
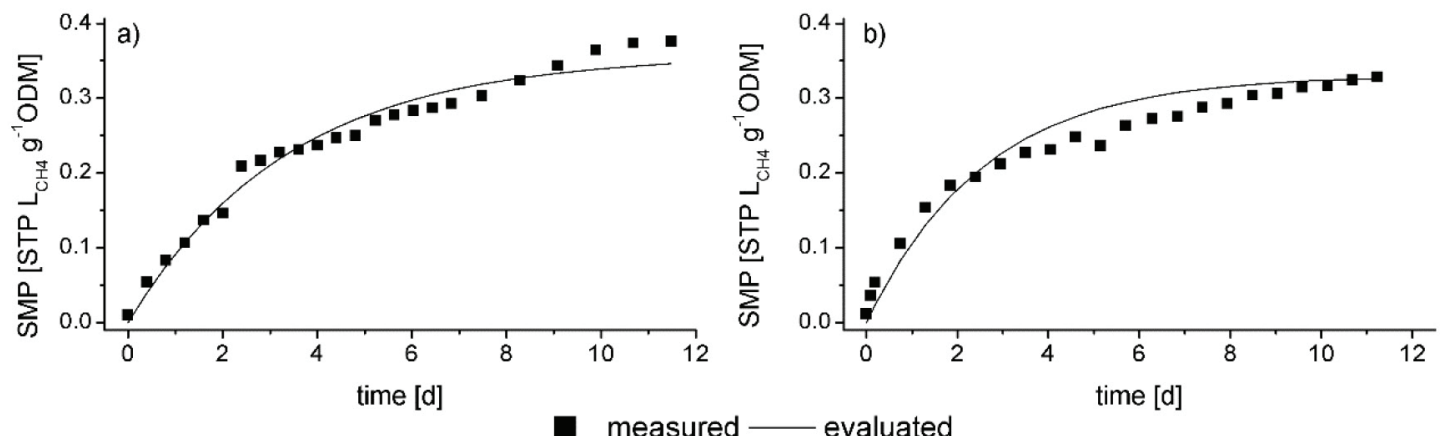

Fig. 2 - Fitting results: a) $M S$, b) $R R$ 

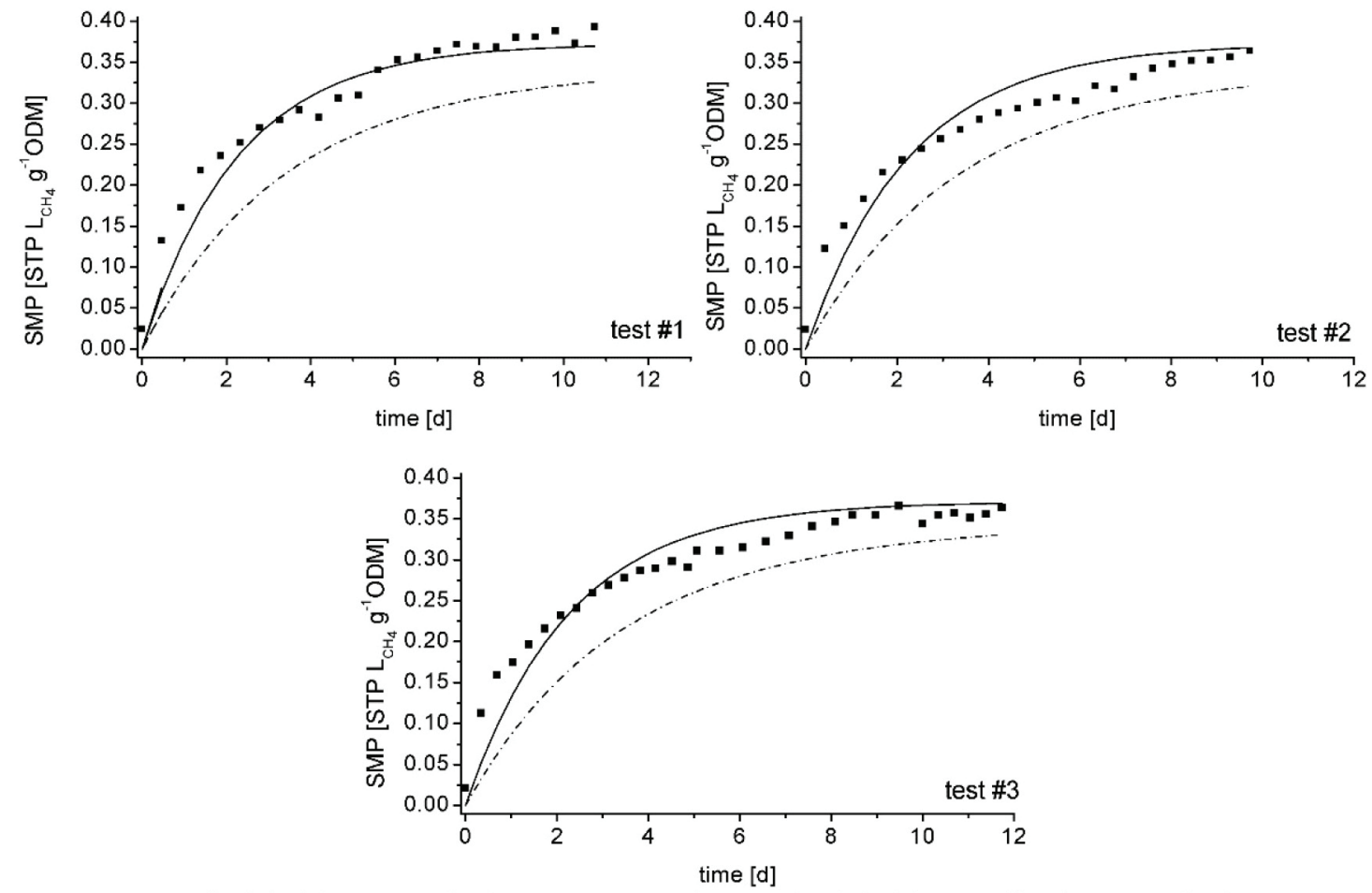

-....... calculated (no synergism) a measured $—$ simulated (accounting for synergism)

Fig. 3 - Evaluation of synergistic effects: scattered curve represents the measured methane production, dotted curve represents the predicted production in the hypothesis of no synergism, continuous line is the simulated production accounting for synergism

The $\triangle S M P_{\text {blend }}$ represent the relative change in $S M P_{u l t}$ compared to what would be expected based on mono-digestion tests ${ }^{46}$. Its value was determined as:

$$
\Delta S M P_{\text {blend }}=\frac{S M P_{\text {blend }, \text { ult }}}{\left(S M P_{M S, u l t} \cdot x_{M S}+S M P_{R R, u l t} \cdot x_{R R}\right)}-1
$$

If co-digestion had no effect on methane yield compared to mono-digestion, $\triangle S M P_{\text {blend }}$ would equal 0.

Analogously, $\Delta k_{\text {blend }}$ is the relative change in solubilization rate constant due to co-digestion:

$$
\Delta k_{\text {blend }}=\frac{k_{\text {blend }}}{\left(k_{M S, \text { sol }} \cdot x_{M S}+k_{R R, s o l} \cdot x_{R R}\right)}-1
$$

The kinetic equation (4) was then reformulated as:

$$
S M P_{(t)}=S M P_{\text {blend }} \cdot\left(1-e^{\left(-k_{\text {sol }, \text { blend } d} \cdot t\right)}\right)
$$

where $S M P_{\text {blend }}$ and $k_{\text {sol, blend }}$ are, respectively:

$$
S M P_{\text {blend }}=\left(S M P_{M S, \text { ult }} \cdot x_{M S}+S M P_{R R, \text { ult }} \cdot x_{R R}\right) \cdot\left(1+\Delta S M P_{\text {blend }}\right)
$$

$k_{\text {blend }}=\left(k_{M S, \text { sol }} \cdot x_{M S}+k_{R R, \text { sol }} \cdot x_{R R}\right) \cdot\left(1+\Delta k_{\text {sol, blend }}\right)$
Table 5 -Co-digestion parameters

\begin{tabular}{c|c|c}
\hline Parameter & Unit & Value \\
\hline$S M P_{\text {blend, ult }}$ & {$\left[\mathrm{STP} \mathrm{L} \mathrm{CH}_{4} \mathrm{~g}^{-1} \mathrm{ODM}\right]$} & 0.373 \\
$k_{\text {sol, blend }}$ & {$\left[\mathrm{d}^{-1}\right]$} & 0.439 \\
$\triangle S M P_{\text {blend }}$ & {$[-]$} & 0.08 \\
$\triangle k_{\text {sol, blend }}$ & {$[-]$} & 0.48 \\
\hline
\end{tabular}

Fig. 3 shows the specific methane production simulated with equation (8). As highlighted by simulation results, presented in Table 5, the synergism due to the co-digestion had a marked effect mainly on the solubilization rate, the value of which was higher than that obtained with mono-digestion of MS and RR. Indeed, the relative increment $\Delta k_{\text {blend }}$ was found significantly higher than zero. Lower improvements were observed in the ultimate methane potential, with a relative change $\triangle S M P_{\text {blend }}$ equal to 0.08 . Similar results were found by Astals et al. ${ }^{15}$ who concluded that AcoD leads to an improvement mainly of the $\mathrm{AD}$ kinetics.

\section{Conclusions}

The synergistic effects due to anaerobic co-digestion of maize silage and red chicory waste were assessed by means of anaerobic biodegradability 
tests followed by methane production simulation. Results showed that blending the two substrates led to an improvement of the digestion process in comparison with the performance obtained from the mono-digestion of each single substrate. Synergistic effects concerned the solubilization process of the complex particulate substances with no significant increase in the ultimate methane potential.

\section{ACKNOWLEDGEMENTS}

The authors wish to thank Doriana Osmani for her cooperation in the laboratory tests.

\section{References}

1. Olsson, L., Fallde, M., Waste(d) potential: A socio-technical analysis of biogas production and use in Sweden, J. Clean. Prod. 98 (2014) 107. doi: https://doi.org/10.1016/j.jclepro.2014.02.015

2. Scano, E. A., Asquer, C., Pistis, A., Ortu, L., Demontis, V., Cocco, D., Biogas from anaerobic digestion of fruit and vegetable wastes: Experimental results on pilot-scale and preliminary performance evaluation of a full-scale power plant, Energ. Convers. Manage. 77 (2014) 22. doi: https://doi.org/10.1016/j.enconman.2013.09.004

3. Eurobserv'er, Biogas barometer 2017, https://www.eurobserv-er.org/category/all-biogas-barometers/ (Accessed August 2018).

4. EBA European Biogas association, Statistical reports 2017, http:/european-biogas.eu/2017/12/14/eba-statistical-report-2017-published-soon/ (Accessed August 2018).

5. Negri, M., Bacenetti, J., Manfredini, A., Lovarelli, D., Fiala, M., Maggiore, T. M., Bocchi, S., Evaluation of methane production from maize silage by harvest of different plant portions, Biomass. Bioenerg. 67 (2014) 339. doi: https://doi.org/10.1016/j.biombioe.2014.05.016

6. Bouallagui, H., Lahdheb, E., Ben Romdan, E., Rachdi, B., $H a m d i, M$. Improvement of fruit and vegetable waste anaerobic digestion performance and stability with co-substrate addition, J. Environ. Manage. 90 (2009) 1844. doi: https://doi.org/10.1016/j.jenvman.2008.12.002

7. Lo, H. M., Kurniawan, T. A., Sillanpaa, M. E. T., Pai, T. Y., Chiang, C. F., Chao, K. P., Liu, M. H., Chuang, S. H., Banks, C. J., Wang, S. C., Lin, K. C., Lin, C. Y., Liu, W. F., Cheng, P. H., Chen, C. K., Chiu, H. Y., Wu, H. Y., Modelling biogas production from organic fraction of MSW co-digested with MSWI ashes in anaerobic bioreactors, Bioresour. Technol. 101 (2010) 6329.

doi: https://doi.org/10.1016/j.biortech.2010.03.048

8. Anjum, M., Khalid, A., Qadeer, S., Miandad, R., Synergistic effect of co-digestion to enhance anaerobic degradation of catering waste and orange peel for biogas production, Waste Manag. Res. 35 (2017) 967.

doi: https://doi.org/10.1177/0734242X17715904

9. Zahan, Z., Othman, M. Z., Muster, T. H., Anaerobic digestion/co-digestion kinetic potentials of different agro-industrial wastes: A comparative batch study for $\mathrm{C} / \mathrm{N}$ optimization, Waste manage. 71 (2018) 663.

10. Vivekanand, V., Mulat, D. G., Eijsink, V. G. H., Horn, S. J., Synergistic effects of anaerobic co-digestion of whey, manure and fish ensilage, Bioresour. Technol. 249 (2018) 35. doi: https://doi.org/10.1016/j.biortech.2017.09.169
11. Farhat, A., Manai, I., Gtari, M., Bouallagui, H., Effect of enhancing nutrient balance in anaerobic digester feedstock by co-substrate addition on the microbial diversity and energy production from municipal sewage sludge, J. Biosci. Bioeng. 126 (2018) 497. doi: https://doi.org/10.1016/j.jbiosc.2018.04.014

12. García-Gen, S., Rodríguez, J., Lema, J. M., Optimisation of substrate blends in anaerobic co-digestion using adaptive linear programming, Bioresour. Technol. 173 (2014) 159. doi: https://doi.org/10.1016/j.biortech.2014.09.089

13. Wang, X., Yang, G., Li, F., Feng, Y., Ren, G., Han, X., Evaluation of two statistical methods for optimizing the feeding composition in anaerobic co-digestion: Mixture design and central composite design, Bioresour. Technol. 131 (2013) 172. doi: https://doi.org/10.1016/j.biortech.2012.12.174

14. Xie, S., Hai, F. I., Zhan, X., Guo, W., Ngo, H. H., Price, W. E., Nghiem, L. D., Anaerobic co-digestion: A critical review of mathematical modelling for performance optimization, Biores. Technol. 222 (2016) 498. doi: https://doi.org/10.1016/j.biortech.2016.10.015

15. Astals, S., Batstone, D. J., Mata-Alvarez, J., Jensen, P. D., Identification of synergistic impacts during anaerobic co-digestion of organic wastes, Bioresour. Technol. 169 (2014) 421. doi: https://doi.org/10.1016/j.biortech.2014.07.024

16. APHA, AWWA and WPCF, Standard Methods for the Examination of Water and Wastewater, 17th edition. American Water Works Association and Water Pollution Control Federation, Washington, DC, 1989.

17. Raposo, F., de la Rubia, M. A., Borja, R., Alaiz, M., Assessment of a modified and optimised method for determining chemical oxygen demand of solid substrates and solutions with high suspended solid content, Talanta 76 (2008) 448. doi: https://doi.org/10.1016/j.talanta.2008.03.030

18. Triolo, J. M., Sommer, S. G., Møller, H. B., Weisbjerg, M. $R$., Jiang, $X$. $Y$., A new algorithm to characterize biodegradability of biomass during anaerobic digestion: Influence of lignin concentration on methane production potential, Bioresour. Technol. 102 (2011) 9395. doi: https://doi.org/10.1016/j.biortech.2011.07.026

19. Herrmann, C., Heiermann, M., Idler, C., Effects of ensiling, silage additives and storage period on methane formation of biogas crops, Bioresour. Technol. 102 (2011) 5153. doi: https://doi.org/10.1016/j.biortech.2011.01.012

20. Colussi, I., Cortesi, A., Del Piccolo, C., Gallo, V., Rubesa-Fernandez, A. S., Vitanza, R., Improvement of methane yield from maize silage by a two-stage anaerobic process, Chem. Eng. Trans. 32 (2013) 151.

21. Rath, J., Heuwinkel, H., Taube, F., Herrmann, A., Predicting specific biogas yield of maize-validation of different model approaches, Bioenerg. Res. 8 (2015) 832. doi: https://doi.org/10.1007/s12155-014-9562-1

22. Herrmann, C., Idler, C., Heiermann, M., Biogas crops grown in energy crop rotations: Linking chemical composition and methane production characteristics, Bioresour. Technol. 206 (2016) 23. doi: https://doi.org/10.1016/j.biortech.2016.01.058

23. Planinic, M., Zelic, B., Cubel, I., Bucic-Kojic, A., Tišma, $M$., Corn forage biological pretreatment by Trametes versicolor in a tray bioreactor, Waste Manag. Res. 34 (2016) 802.

doi: https://doi.org/10.1177/0734242X16654979 
24. Lucarini, M., D'Evoli, L., Tufi, S., Gabrielli, P., Paoletti, S., Di Ferdinando, S., Lombardi-Boccia, G., Influence of growing system on nitrate accumulation in two varieties of lettuce and red radicchio of Treviso, J. Sci. Food Agric. 92 (2011) 2796. doi: https://doi.org/10.1002/jsfa.5526

25. Ritota, M., Casciani, L., Valentini, M., PGI chicory (Cichorium intybus L.) traceability by means of HRMAS-NMR spectroscopy: A preliminary study, J. Sci. Food Agric. 93 (2013) 1665.

doi: https://doi.org/10.1002/jsfa.5947

26. ISTAT (Istituto Italiano di Statistica - Italian Institute of Statistics), Consultazione dati agricoltura e zootecnia, tavola C10, http://agri.istat.it/sag_is_pdwout/jsp/dawinci.jsp?q= $\mathrm{plC} 100000020000063200 \& \mathrm{an}=2016 \& \mathrm{ig}=1 \& \mathrm{ct}=258 \& \mathrm{id}=1$ 5A|18A|28A (Accessed July 2017)

27. Bortolini, L., Nicoletto, C., Sambo, P., Evans, M. R., Radicchio cultivation under different sprinkler irrigation systems, Contemp. Eng. Sci. 9 (2016) 345.

28. Tosini, F., Le varietà di radicchio: confronto in Veneto. L'informatore agrario (supplemento) 60 (2004). 37.

29. CREA (Consiglio per la Ricerca in agricoltura e l'analisi dell'Economia Agraria), http://nut.entecra.it/646/tabelle_ di_composizione_degli_alimenti.html?idalimento $=005440$ \& quant $=100$ (Accessed August 2018).

30. Wahid, R., Ward, A. J., Møller, H. B., Søegaard, K., Eriksen, $J$., Biogas potential from forbs and grass-clover mixture with the application of near infrared spectroscopy, Bioresour. Technol. 198 (2015) 124.

doi: https://doi.org/10.1016/j.biortech.2015.08.154

31. Li, Y., Zhang, R., Liu, G., Chen, C., He, Y., Liu, X., Comparison of methane production potential, biodegradability, and kinetics of different organic substrates, Bioresour. Technol. 149 (2013) 565

doi: https://doi.org/10.1016/j.biortech.2013.09.063

32. Thomsen, S. T., Spliid, H., Østergård, H., Statistical prediction of biomethane potentials based on the composition of lignocellulosic biomass, Bioresour. Technol. 154 (2014) 80. doi: https://doi.org/10.1016/j.biortech.2013.12.029

33. Angelidaki, I., Sanders, W., Assessment of the anaerobic biodegradability of macropollutants, Rev. Environ. Sci. Biotechnol. 3 (2004) 117. doi: https://doi.org/10.1007/s11157-004-2502-3

34. Buswell, A. M., Neave, S. L., Laboratory studies of sludge digestion. Department of Registration and Education, 1930.

35. Colussi, I., Cortesi, A., Gallo, V., Rubesa-Fernandez, A. S., Vitanza, $R$., Methane production from solid potatoes by a procedure simulating a bench-scale sequencing batch reactor anaerobic process, Chem. Biochem. Eng. Q. 28 (2014) 119.

36. Biernacki, P., Steinigeweg, S., Borchert, A., Uhlenhut, F., Application of Anaerobic Digestion Model No. 1 for describing anaerobic digestion of grass, maize, green weed silage, and industrial glycerine, Bioresour. Technol. 127 (2013a) 188.

doi: https://doi.org/10.1016/j.biortech.2012.09.128
37. Garcia-Gen, S., Sousbie, P., Rangaraj, G., Lema, J. M., Rodríguez, J., Steyer, J. P., Kinetic modelling of anaerobic hydrolysis of solid wastes, including disintegration processes, Waste Manage. 35 (2015) 96.

doi: https://doi.org/10.1016/j.wasman.2014.10.012

38. Tišma, M., Planinić, M., Bucić-Kojić, A., Panjičko, M., Zupančič, G. D., Zelić, B., Corn silage fungal-based solid-state pretreatment for enhanced biogas production in anaerobic co-digestion with cow manure, Bioresour. Technol. 253 (2018) 220. doi: https://doi.org/10.1016/j.biortech.2018.01.037

39. Panjičko, M., Zupančič, G. D., Fanedl, L., Logar, R. M., Tišma, M., Zelić, B., Biogas production from brewery spent grain as a mono-substrate in a two-stage process composed of solid-state anaerobic digestion and granular biomass reactors, J. Clean. Prod. 166 (2017) 519. doi: https://doi.org/10.1016/j.jclepro.2017.07.197

40. Gali, A., Benabdallah, T., Astals, S., Mata-Alvarez, J., Modified version of ADM1 model for agro-waste application, Bioresour. Technol. 100 (2009) 2783. doi: https://doi.org/10.1016/j.biortech.2008.12.052

41. Batstone, D. J., Keller, J., Angelidaki, I., Kalyuzhnyi, S. V., Pavlostathis, S. G., Rozzi, A., Sanders, W. T. M., Siegrist, H., Vavilin, V. A., Anaerobic digestion model no.1 (ADM1), Scientific and Technical Report No.13. IWA Publishing, London, 2002.

42. Astals, S., Esteban-Gutiérrez, M., Fernández-Arévalo, T., Aymerich, E., Garcia-Heras, J. L., Mata-Alvarez, J., Anaerobic digestion of seven different sewage sludges: A biodegradability and modelling study, Water Res. 47 (2013) 6033. doi: https://doi.org/10.1016/j.watres.2013.07.019

43. Feng, Y., Behrendt, J., Wendland, C., Otterpohl, R., Parameter analysis of the IWA anaerobic digestion model no.1 for the anaerobic digestion of blackwater with kitchen refuse, Water Sci. Technol. 54 (2006) 139. doi: https://doi.org/10.2166/wst.2006.535

44. Mata-Alvarez, J., Dosta, J., Romero-Güiza, M. S., Fonoll, $X$., Peces, M., Astals S., A critical review on anaerobic co-digestion achievements between 2010 and 2013, Renew. Sustain Energy Rev. 36 (2014) 412. doi: https://doi.org/10.1016/j.rser.2014.04.039

45. Aichinger, P., Wadhawan, T., Kuprian, M., Higgins, M., Ebner, C., Fimml, C., Murthy, S., Wett, B., Synergistic co-digestion of solid-organic-waste and municipal sewage-sludge: 1 plus 1 equals more than 2 in terms of biogas production and solids reduction, Water Res. 87 (2015) 416. doi: https://doi.org/10.1016/j.watres.2015.07.033

46. Poulsen, T. G., Adelard, L., Improving biogas quality and methane yield via co-digestion of agricultural and urban biomass wastes, Waste. Manage. 54 (2016) 118. doi: https://doi.org/10.1016/j.wasman.2016.05.020

47. De Boever, J. L., Cottyn, B. G., De Brabander, D. L., Vanacker, J. M., Boucqué, Ch. V., Prediction of the feeding value of maize silages by chemical parameters, in vitro digestibility and NIRS, Anim. Feed. Sci. Technol. 66 (1997) 211. doi: https://doi.org/10.1016/S0377-8401(96)01101-7 